\title{
A rapid and accurate method for the detection of four aminoglycoside modifying enzyme drug resistance gene in clinical strains of Escherichia coli by a multiplex polymerase chain reaction
}

\author{
Yaoqiang Shi ${ }^{\text {Equal first author, } 1,2}$, Chao Li ${ }^{\text {Equal first author, } 1,2}$, Guangying Yang ${ }^{1,2}$, Xue-shan Xia ${ }^{1,2}$, Xiaoqin Mao ${ }^{3}$, Yue Fang ${ }^{1,2}$, A-

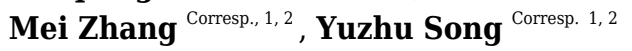 \\ ${ }^{1}$ Faculty of life science and technology, Kunming University of Science and Technology, Kunming, Yunnan, China \\ 2 Molecular Medicine Center of Yunnan Province, Kunming, Yunnan, China \\ 3 The First People's Hospital of Yunnan Province, Kunming, Yunnan, China \\ Corresponding Authors: A-Mei Zhang, Yuzhu Song \\ Email address: zam1980@yeah.net, yuzhusong@kmust.edu.cn
}

Background. Antibiotics are highly effective drugs used in the treatment of infectious diseases. Aminoglycoside antibiotics are one of the most common antibiotics in the treatment of bacterial infections. However, the development of drug resistance against those medicines is becoming a serious concern.AIM: This study aimed to develop an efficient, rapid, accurate, and sensitive detection method that is applicable for routine clinical use.Methods. Escherichia coli was used as a model organism to develop a rapid, accurate, and reliable multiplex polymerase chain reaction (M-PCR) for the detection of four aminoglycoside modifying enzyme (AME) resistance genes $A a c\left(6^{\prime}\right)-I b, A a c(3)-I I$, Ant( (3")-Ia, and Aph(3')-la. M-PCR was used to detect the distribution of AME resistance genes in 237 clinical strains of $E$. coli. The results were verified by simplex polymerase chain reaction (S-PCR). Results. Results of M-PCR and S-PCR showed that the detection rates of $A a c\left(6^{\prime}\right)-I b, A a c(3)-I I, A n t\left(3^{\prime \prime}\right)-l a$, and $A p h\left(3^{\prime}\right)-l a$ were $32.7 \%, 59.2 \%, 23.5 \%$, and $16.8 \%$, respectively, in 237 clinical strains of $E$. coli. Compared with the traditional methods for detection and identification, the rapid and accurate M-PCR detection method was established to detect AME drug resistance genes. This technique can be used for the clinical detection as well as the surveillance and monitoring of the spread of those specific antibiotic resistance genes. 
1 A rapid and accurate method for the detection of four aminoglycoside modifying enzyme

2 drug resistance gene in clinical strains of Escherichia coli by a multiplex polymerase chain

3 reaction

4 Yaoqiang Shi ${ }^{1,2}$, a Chao Li ${ }^{1,2}$, a Guangying Yang ${ }^{1,2}$, Xue-shan $\mathrm{Xia}^{1,2}$, Xiaoqin Mao ${ }^{3}$, Yue Fang ${ }^{1,}$

$5 \quad 2$, A-Mei Zhang ${ }^{1,2, *}$, Yuzhu Song ${ }^{1,2, *}$

$6{ }^{1}$ Faculty of Life Science and Technology, Kunming University of Science and Technology,

7 Kunming, 650500, Yunnan, China

$8{ }^{2}$ Molecular Medicine Center of Yunnan Province, Kunming, 650500, Yunnan, China

$9 \quad 3$ First People's Hospital of Yunnan Province, Kunming, 650500, Yunnan, China

10 a Author Yaoqiang Shi, author Chao Li contributed equally to this manuscript

11 * Corresponding author

12 Dr. A-Mei Zhang, Faculty of Life Science and Technology, Kunming University of Science and

13 Technology, Kunming, Yunnan 650500, China. Tel/Fax: 86-871-65939528; E-mail:

14 zam1980@yeah.net

15 Dr. Yuzhu Song, Faculty of Life Science and Technology, Kunming University of Science and

16 Technology, Kunming, Yunnan 650500, China. Tel/Fax: 86-871-65939528; E-mail:

17 yuzhusong@kmust.edu.cn 


\section{Abstract}

24 Background. Antibiotics are highly effective drugs used in the treatment of infectious diseases.

Aminoglycoside antibiotics are one of the most common antibiotics in the treatment of bacterial infections. However, the development of drug resistance against those medicines is becoming a serious concern.

AIM: This study aimed to develop an efficient, rapid, accurate, and sensitive detection method that is applicable for routine clinical use.

Methods. Escherichia coli was used as a model organism to develop a rapid, accurate, and reliable multiplex polymerase chain reaction (M-PCR) for the detection of four aminoglycoside modifying enzyme (AME) resistance genes $A a c\left(6^{\prime}\right)-I b, A a c(3)-I I, A n t\left(3^{\prime \prime}\right)-I a$, and $A p h\left(3^{\prime}\right)-I a$. MPCR was used to detect the distribution of AME resistance genes in 237 clinical strains of $E$. coli. The results were verified by simplex polymerase chain reaction (S-PCR).

Results. Results of M-PCR and S-PCR showed that the detection rates of $A a c\left(6^{\prime}\right)-I b, A a c(3)-I I$, $\operatorname{Ant}\left(3^{\prime \prime}\right)-I a$, and $\operatorname{Aph}\left(3^{\prime}\right)-I a$ were $32.7 \%, 59.2 \%, 23.5 \%$, and $16.8 \%$, respectively, in 237 clinical strains of E. coli. Compared with the traditional methods for detection and identification, the rapid and accurate M-PCR detection method was established to detect AME drug resistance genes. This technique can be used for the clinical detection as well as the surveillance and monitoring of the spread of those specific antibiotic resistance genes.

41 Keywords: Molecular detection; Polymerase chain reaction; Multiplex polymerase chain 42 reaction; Aminoglycoside modifying enzyme drug resistance gene 
44

45

46

47

48

49

50

51

52

53

54

55

56

57

58

59

60

61

62

63

\section{Introduction}

With the abuse and misuse of antibiotics, bacterial tolerance is becoming an increasingly serious concern (Ferri et al. 2017; Levin-Reisman et al. 2017), leading to the emergence of a series of drug-resistant bacteria (multi-drug-resistance [MDR], extensively-drug-resistant [XDR], and pan-drug-resistant [PDR]) (Healey et al. 2016; Planet 2017). MDR is defined as acquired non-susceptibility to at least one agent in three or more antimicrobial categories. XDR is defined as non-susceptibility to at least one agent in all but two or fewer antimicrobial categories. PDR is defined as non-susceptibility to all agents in all antimicrobial categories (Magiorakos et al. 2012). Aminoglycoside antibiotics (Amikacin, Gentamicin, Tobramycin, Kanamycin, Netilmicin, Streptomycin, and Neomycin.) (Doi et al. 2016; Krause et al. 2016; Yadegar et al. 2009) are mainly used to treat infections caused by aerobic Gram-negative bacteria, such as Escherichia coli and Klebsiella pneumoniae, and non-fermenters like Pseudomonas aeruginosa (Jana \& Deb 2006; Magnet \& Blanchard 2005; Zavascki et al. 2017). However, bacteria can easily develop tolerance to aminoglycoside antibiotics due to the production of aminoglycoside modifying enzymes (AMEs) (Haidar et al. 2016; Khosravi et al. 2017) and the rapid transmission of AME resistance genes in pathogenic bacteria (Ramirez \& Tolmasky 2010). The severity of antibiotic tolerance has become a global worldwide concern.

1 The theme of World Health Day in 2011 was "Combat Drug Resistance: No action today, No cure tomorrow" (Chellat et al. 2016; Tseng et al. 2012), whereas that in 2018 was "Change Can't Wait. Our Time with Antibiotics is Running Out". In such a severe situation of drug resistance, 
64 there is an urgent need to identify the species of bacteria and their drug resistance genes

65 accurately and quickly to guide clinical drug use (Brossier et al. 2017; Mu et al. 2016). This need

66 led to the establishment of a rapid, accurate, and economical method to detect pathogens and

67 their drug resistance as early as possible. Such a technique is helpful for the rational use of drugs

68 in clinical practice, as well as of great clinical significance to control and shorten the course of

69 the disease (Laamiri et al. 2016).

70 Although the traditional method for bacterial resistance identification is simple and

71 economical, identification is completed in about 4-7 days (Jami Al-Ahmadi \& Zahmatkesh

72 Roodsari 2016; Phaneuf et al. 2013). It includes several steps, such as bacterial culture, single

73 colony isolation, colony morphology observation, biochemical identification, and serotype

74 identification (Panek et al. 2016). The accuracy of this method is low, and errors easily occur

75 (Tuttle et al. 2011). The main methods used to test drug sensitivity include the disk diffusion

76 method, E-test, dilution method (agar and broth dilution method), and automatic instruments

77 (Biswas 2016; Ghosh et al. 2015). Such methods have the advantages of low cost, easy

78 operation, and strong flexibility. However, they also feature some inevitable disadvantages, such

79 as slow, empirical dependence. With the development of biological science and technology,

80 many new biological technologies have entered people's lives. Interspecific and intraspecific

81 conserved nucleic acid sequences have been discovered in succession (Nagar \& Hahsler 2013),

82 and various bioinformatics and molecular biological techniques based on nucleic acid

83 amplification have been used to identify pathogens; an example of such techniques is polymerase

84 chain reaction (PCR), which has become the gold standard (Tuttle et al. 2011). 
What's more, M-PCR can also be used in the simultaneous detection of multidrug resistance strains. 
106

107

108

109

110

111

112

113

114

115

116

117

118

119

120

121

122

123

124

125

126

\section{Bacterial strains and culture}

The 237 clinical strains of E. coli used in this study were provided, isolated, cultured, and identified by the First People's Hospital of Yunnan Province. All the strains were cultured in Luria-Bertani (LB) liquid medium in a shaking incubator at $37^{\circ} \mathrm{C}$ and $180 \mathrm{rpm}$ for $12 \mathrm{~h}$. The bacterial genome was extracted using the TIANamp genomic DNA kit following the manufacturer's protocol and then stored at $-40^{\circ} \mathrm{C}$ for further experiments.

\section{Search of drug resistance genes searching and design of primers}

Four AME resistance genes $A a c\left(6^{\prime}\right)-I b, A n t\left(3^{\prime \prime}\right)-I a, A p h\left(3^{\prime}\right)-I a$, and $A a c(3)-I I$ were downloaded from the Comprehensive Antibiotic Resistance Database (https://card.mcmaster.ca/). The primers were designed according to the conservative region and synthesized by TSINGKE Biological Technology. The primers sequences are shown in Table 1.

\section{Establishment of S-PCR reaction system}

S-PCR was performed using 2X Tsingke Master Mix, which was purchased from Tsingke Biotech Co., Ltd. (Kunming, China). According to the manufacturer's protocol, the S-PCR reaction system containing $12.5 \mu \mathrm{L}$ of $2 \mathrm{X}$ Tsingke Master Mix, $1 \mu \mathrm{L}$ of primers $(10 \mu \mathrm{M})$, and 1 $\mu \mathrm{g}$ of DNA template from each strain was added with nuclease-free water up to $25 \mu \mathrm{L}$. The reactions were performed in a GeneAmp PCR System 9700 (Thermo Fisher Scientific, Inc., Waltham, MA, USA) with the following amplification conditions: pre-denaturation at $95^{\circ} \mathrm{C}$ for 5 min; 30 cycles of denaturation at $95^{\circ} \mathrm{C}$ for $30 \mathrm{~s}$, annealing at $57^{\circ} \mathrm{C}, 59^{\circ} \mathrm{C}, 56^{\circ} \mathrm{C}$, and $57^{\circ} \mathrm{C}$ $\left(A a c\left(6^{\prime}\right)-I b, A n t\left(3^{\prime \prime}\right)-I a, A p h\left(3^{\prime}\right)-I a\right.$, and $\left.A a c(3)-I I\right)$ for 30 s; extension at $72^{\circ} \mathrm{C}$ for $30 \mathrm{~s}$; and a final extension at $72^{\circ} \mathrm{C}$ for $7 \mathrm{~min}$. The S-PCR products were verified using gel electrophoresis on a 
127

128

129

130

131

132

133

134

135

136

137

138

139

140

141

142

143

144

145

146

147

2\% agarose gel and stained with GelStain (Beijing Transgen Biotech Co., Ltd., Beijing, China).

\section{Construction and verification of positive plasmids}

The positive plasmids with resistance genes were constructed as described in a previous study (Li et al. 2019). In brief, the DNA fragments of the target genes were obtained by PCR reactions using the genomic DNA of $E$. coli as a template. The target fragment was inserted into the pMD 19-T simple vector and transformed into JM109-competent cells. The positive clones were selected for overnight culture to extract plasmids. Finally, the copies of recombinant plasmids were calculated.

\section{Sensitivity and accuracy evaluation of S-PCR}

After the positive plasmids were constructed, the sensitivity of S-PCR reactions was evaluated using the serially diluted 10 -fold positive plasmids. According to the resistance gene information of 237 clinical strains of E. coli provided by the First People's Hospital of Yunnan Province, the strains with $A a c\left(6^{\prime}\right)-I b, A n t\left(3^{\prime \prime}\right)-I a, A p h\left(3^{\prime}\right)-I a$, and $A a c(3)-I I$ resistance genes were screened to evaluate accuracy.

\section{Establishment of M-PCR reaction system and accuracy evaluation of M-PCR}

The M-PCR was performed by using a Multiplex PCR kit (Nanjing Vazyme Biotechnology Co., Ltd., Nanjing, China). According to the manufacturer's protocol, the M-PCR reaction system containing $25 \mu \mathrm{L}$ of $2 \mathrm{X}$ Multiplex Buffer, $10 \mu \mathrm{L}$ of $5 \mathrm{X}$ Multiplex GC Enhancer, $1 \mu \mathrm{L}$ of each primer $(10 \mu \mathrm{M}), 1 \mu \mathrm{L}$ of Multiplex DNA polymerase, and $1 \mu \mathrm{g}$ of DNA template from each strain, was added with nuclease-free water up to $50 \mu \mathrm{L}$. The reactions were performed in a GeneAmp PCR System 9700 (Thermo Fisher Scientific, Inc., Waltham, MA, USA) with the 
148 following amplification conditions: pre-denaturation at $95{ }^{\circ} \mathrm{C}$ for $5 \mathrm{~min}$, followed by 30 cycles of

149 denaturation at $95{ }^{\circ} \mathrm{C}$ for $30 \mathrm{~s}$, annealing at $60{ }^{\circ} \mathrm{C}$ for $3 \mathrm{~min}$, extension at $72{ }^{\circ} \mathrm{C}$ for $3 \mathrm{~min}$, and a

150 final extension at $72{ }^{\circ} \mathrm{C}$ for $30 \mathrm{~min}$. The M-PCR products were verified by gel electrophoresis on

$1512 \%$ agarose gel and stained with GelStain (Beijing Transgen Biotech Co., Ltd., Beijing, China).

152 Based on the drug sensitivity information of 237 clinical strains of $E$. coli, five isolates

153 (1611NY0004, 1611UR0282, 1611SP0549, 1611UR0062, and 1611UR0215) previously tested

154 for the $A a c\left(6^{\prime}\right)-I b, A n t\left(3^{\prime \prime}\right)-I a, A p h\left(3^{\prime}\right)-I a$, and $A a c(3)-I I$ by S-PCR were tested for the M-PCR.

155 Sensitivity evaluation of M-PCR

156 The sensitivity of M-PCR was performed by using gradient dilution plasmids and bacterial 157 solution. The four equal concentration plasmids with $\operatorname{Aac}\left(6^{\prime}\right)-I b, \operatorname{Ant}\left(3^{\prime \prime}\right)-I a, A p h\left(3^{\prime}\right)-I a$, and $158 \operatorname{Aac}(3)-I I$ resistance genes were mixed together and serially diluted to 10 -fold $\left(10^{8}-10^{0}\right)$. E. coli 159 1611NY0004 was selected as the representive strain for sensitivity evaluation. The stain was 160 cultured in LB liquid medium to $\mathrm{OD}_{600}=1$, and the colony-forming units of bacterial solution were calculated by the plate count method. The bacterial solution was serially diluted as 10 -fold $162\left(10^{8}-10^{0}\right)$.

\section{M-PCR detection for clinical samples}

All the 237 clinical E. coli strains were provided and identified by the First People's Hospital of Yunnan Province and used in the accuracy evaluation of S-PCR and M-PCR.

\section{Results}

Establishment of S-PCR reaction system

The positive plasmids with drug resistance genes (Aac(6')-Ib, Ant(3")-Ia, Aph(3')-Ia, and 
$169 \operatorname{Aac}(3)-I I)$ were successfully constructed, with $3 \times 10^{9}, 4 \times 10^{9}, 5 \times 10^{9}$, and $4 \times 10^{10}$ copies $/ \mu \mathrm{L}$

$170(114.5,141.2,156.8$, and $153.2 \mathrm{ng} / \mu \mathrm{L})$, respectively. The S-PCR reaction template comprised the

171 serially diluted plasmids. Meanwhile, the four drug resistance genes were detected in the 237

172 clinical strains of E. coli, and the bacterial solution was the S-PCR template. As shown in Figure

1731 , the limitation for the detection of the four drug resistance genes was $10^{0} \operatorname{copies} / \mu \mathrm{L}$. The

174 accuracy rate for the detection of drug resistance genes was $100 \%$ (partially representative

175 results), which was consistent with the hospital data (Supplement Table 1).

176 Establishment of M-PCR reaction system

177 After the S-PCR reaction system was established and optimized (data not shown), the M-

178 PCR reaction system was constructed. As shown in Figure 2, $\operatorname{Aac}\left(6^{\prime}\right)-I b, \operatorname{Ant}\left(3^{\prime \prime}\right)-\operatorname{Ia}, \operatorname{Aph}\left(3^{\prime}\right)-\operatorname{Ia}$, 179 and $\mathrm{Aac}(3)-I I$ with 112, 180, 317, and 379 bp, respectively, were amplified successfully. E. coli 1801611 NY0004 with the four drug resistance genes was used as the positive control template for the 181 M-PCR reaction. In the M-PCR reaction system, the four drug resistance genes could be 182 amplified well simultaneously.

\section{Accuracy evaluation of M-PCR}

The five clinical E. coli strains (1611NY0004, 1611UR0282, 1611SP0549, 1611UR0062,

and 1611UR0215) with four resistance genes were screened for the accuracy evaluation of M-

PCR. The four equal concentration plasmids with $\operatorname{Aac}\left(6^{\prime}\right)-I b, \operatorname{Ant}\left(3^{\prime \prime}\right)-I a, A p h\left(3^{\prime}\right)-I a$, and $\operatorname{Aac}(3)-$

II resistance genes were mixed together as the positive control. As shown in Figure 3, the four consistent with the resistance gene information provided by the hospital. 
190

191

192

193

194

195

196

197

198

199

200

201

202

203

204

205

206

207

208

209

210

\section{Sensitivity evaluation of M-PCR}

The gradient dilution of plasmids and bacterial solution was used in the sensitivity evaluation of M-PCR. The gradient dilution of plasmids was the mixture of the four equal concentration plasmids with $A a c\left(6^{\prime}\right)-I b, A n t\left(3^{\prime \prime}\right)-I a, A p h\left(3^{\prime}\right)-I a$, and $A a c(3)-I I$ resistance gene and sthen erially diluted as 10 -fold $\left(10^{8}-10^{0}\right.$ copies $\left./ \mathrm{mL}\right)$. The E. coli 1611 YY0004 strain was used in the gradient 10 -fold $\left(10^{8}-10^{0} \mathrm{CFU} / \mathrm{mL}\right)$ dilution of bacterial solution for sensitivity evaluation. As shown in Figure 4, the detection system could reach the detection limit of $10^{0} \mathrm{copies} / \mathrm{mL}$ or $10^{\circ} \mathrm{CFU} / \mathrm{mL}$ at the plasmid level and bacterial liquid level.

\section{Detection of clinical samples by multiplex PCR}

All the 237 E. coli strains were detected by S-PCR and M-PCR. The detection results and the accuracy are shown in Supplemental Table 1. The results showed that the detection rates of $A a c\left(6^{\prime}\right)-I b, A a c(3)-I I, A n t\left(3^{\prime \prime}\right)-I a$, and $A p h\left(3^{\prime}\right)-I a$ were $32.7 \%, 59.2 \%, 23.5 \%$, and 16.8\% in 237 clinical strains of $E$. Coli, respectively. These values were consistent with the gene information of the strains given by the hospital.

\section{Discussion}

Antibiotics are considered the most effective drugs in the treatment of infectious diseases (Elder et al. 2016). The emergence of antibiotics changed the outcome of infectious diseases and extended life expectancy (Wagner \& Maynard 2018). However, given the overuse and misuse of antibiotics, MDR strains have emerged (Elder et al. 2016). Therefore, rapid and accurate methods for the detection of bacterial resistance are urgently needed, and the use of antibiotics or antibiotic therapy should be more standardized and technically, where possible, monitored. With 
211 the development of molecular biology and bioinformatics, the detection methods of bacterial

212 drug resistance genes, including PCR, loop-mediated isothermal amplification, and whole

213 genome sequencing (WGS) (Moran et al. 2017; Su et al. 2019), have increased (Tamburro \&

214 Ripabelli 2017). Although WGS is gradually reaching maturity, while sequencing costs are

215 drastically decreasing, it is however still relatively costly, complex in operation and requires for

216 analysis specialised personnel like bioinformaticians, which limits its popularization and

217 application (Quainoo et al. 2017). M-PCR is widely used in the identification and drug resistance

218 detection of bacteria for its rapid, sensitive, economy-friendly, and high-effect characteristics

219 (Pham et al. 2017).

220 Aminoglycoside antibiotics are one of the most widely used antibiotics, and the main reason

221 for aminoglycoside antibiotic resistance is the production of AM. Aminoglycoside antibiotic

222 resistance is related to the AME drug resistance genes $\operatorname{Aac}\left(6^{\prime}\right)-I b, \operatorname{Aac}(3)-I I, \operatorname{Ant}\left(3^{\prime \prime}\right)-I a$, and

223 Aph(3')-Ia (Zarate et al. 2018). Thus, this study designed primers for the four drug resistance

genes and constructed a four-drug resistance genes detection system, which greatly improved the detection efficiency and shortened the detection time.

The MDR gene detection system was established successfully in this experiment, and it exhibited the advantages of high efficiency, rapidity, and high performance-to-price ratio compared with the S-PCR reaction system. The MDR gene detection system also fully met the requirements for the clinical detection of pathogens and drug resistance. In this experiment, the four drug-resistant genes were identified in the five representative $E$. coli MDR bacteria by M-

PCR. The results obtained by M-PCR were consistent with those of S-PCR, thereby indicating 
232 the accuracy of M-PCR. The M-PCR detection system was applied to the detection of 237

233 clinical strains of $E$. coli. On the basis of the drug resistance gene information given by the

234 hospital, the accuracy rate of M-PCR could reach $100 \%$; the detection rates of $A a c\left(6^{\prime}\right)-I b$,

$235 A a c(3)-I I, A n t\left(3^{\prime \prime}\right)-I a$, and $A p h\left(3^{\prime}\right)-I a$ were 32.7\%, 59.2\%, 23.5\%, and 16.8\%, respectively. These

236 findings indicated the potential of reintroducing additional resistant genes into the M-PCR

237 system to detect numerous genes at a time. Even the specific genes of the bacteria could be

added into the M-PCR system for the identification of bacterial species. From the detection rate

of the four aminoglycoside modifying enzyme resistance genes, Aac(3)-II had the highest

detection rate in the 237 clinical strains of E. coli. This result suggested that the resisitance of

three aminoglycoside antibiotics gentamicin, tobramycin, and netilmicin resistance is widespread

in bacterial infections andshould be avoided.

In conclusion, the M-PCR system developed in this study could amplify the four genes with

very extremely high sensitivity to $10^{0}$ copies. The sensitivity rate of M-PCR was higher than that

of most preiously reported studies, which proved the sensitivity of this technique. Moreover, the

M-PCR detection method greatly reduced the detection time and improved the detection

efficiency. M-PCR in this study demonstrated high sensitivity and efficiency, low price, and

other characteristics but not one-to-one correspondence between genotype and phenotype.

249 Therefore, simply detecting genes failed to completely determine the phenotype, but the four

genes selected genes had the highest prevalence of aminoglycoside antibiotic resistance. We

conducted the simultaneous detection of these four genes to compensate for the limitations of 
253

254

255

256

257

258

259

260

261

262

263

264

265

266

267

268

269

270

271

272

273

established to assist medical institutions to predict drug resistance, to provide an accurate direction for clinical drug selection, and to meet the needs of both doctors and patients for rapid diagnosis. In the future, we will propose a rapid drug sensitivity identification technique based on phenotype. We will also combine traditional detection methods with modern molecular techniques, starting from the phenotype, for the accurate identification of bacterial drug resistance.

\section{Acknowledgments}

We are grateful for the strains donated and the drug resistant information provided by the First People's Hospital of Yunnan Province.

\section{References}

Azizi O, Shahcheraghi F, Salimizand H, Modarresi F, Shakibaie MR, Mansouri S, Ramazanzadeh R, Badmasti F, and Nikbin V. 2016. Molecular Analysis and Expression of bap Gene in Biofilm-Forming Multi-Drug-Resistant Acinetobacter baumannii. Rep Biochem Mol Biol 5:62-72.

Biswas B. 2016. Clinical Performance Evaluation of Molecular Diagnostic Tests. J Mol Diagn 18:803-812. 10.1016/j.jmoldx.2016.06.008

Brossier F, Sougakoff W, and French National Reference Center for M. 2017. Molecular detection methods of resistance to antituberculosis drugs in Mycobacterium tuberculosis. Med Mal Infect 47:340-348. 10.1016/j.medmal.2017.04.008

Chamberlain JS, Gibbs RA, Ranier JE, Nguyen PN, and Caskey CT. 1988. Deletion screening of the Duchenne muscular dystrophy locus via multiplex DNA amplification. Nucleic Acids 
275 Chavada R, and Maley M. 2015. Evaluation of a Commercial Multiplex PCR for Rapid

276

277

278

279

280

281

282

283

284

285

286

287

288

289

290

291

292

293

294

Detection of Multi Drug Resistant Gram Negative Infections. Open Microbiol J 9:125135. $10.2174 / 1874285801509010125$

Chellat MF, Raguz L, and Riedl R. 2016. Targeting Antibiotic Resistance. Angew Chem Int Ed Engl 55:6600-6626. 10.1002/anie.201506818

Costello SE, Deshpande LM, Davis AP, Mendes RE, and Castanheira M. 2019. Aminoglycosidemodifying enzyme and 16S ribosomal RNA methyltransferase genes among a global collection of Gram-negative isolates. $J$ Glob Antimicrob Resist 16:278-285. 10.1016/j.jgar.2018.10.020

Doi Y, Wachino JI, and Arakawa Y. 2016. Aminoglycoside Resistance: The Emergence of Acquired 16S Ribosomal RNA Methyltransferases. Infect Dis Clin North Am 30:523-537. 10.1016/j.idc.2016.02.011

Elder DP, Kuentz M, and Holm R. 2016. Antibiotic Resistance: The Need For a Global Strategy. J Pharm Sci 105:2278-2287. 10.1016/j.xphs.2016.06.002

Ferri M, Ranucci E, Romagnoli P, and Giaccone V. 2017. Antimicrobial resistance: A global emerging threat to public health systems. Crit Rev Food Sci Nutr 57:2857-2876. 10.1080/10408398.2015.1077192

Ghosh R, Nagavardhini A, Sengupta A, and Sharma M. 2015. Development of Loop-Mediated Isothermal Amplification (LAMP) assay for rapid detection of Fusarium oxysporum f. sp. ciceris - wilt pathogen of chickpea. BMC Res Notes 8:40. 10.1186/s13104-015-0997-z 
295 Haidar G, Alkroud A, Cheng S, Churilla TM, Churilla BM, Shields RK, Doi Y, Clancy CJ, and

296 Nguyen MH. 2016. Association between the Presence of Aminoglycoside-Modifying

297 Enzymes and In Vitro Activity of Gentamicin, Tobramycin, Amikacin, and Plazomicin

against Klebsiella pneumoniae Carbapenemase- and Extended-Spectrum-beta-

Lactamase-Producing Enterobacter Species. Antimicrob Agents Chemother 60:5208-

300

5214. 10.1128/AAC.00869-16

301

Haldorsen BC, Simonsen GS, Sundsfjord A, Samuelsen O, and Norwegian Study Group on

302

303

304

305

306

307

308

309

310

311

312

313

314

315

Aminoglycoside R. 2014. Increased prevalence of aminoglycoside resistance in clinical isolates of Escherichia coli and Klebsiella spp. in Norway is associated with the acquisition of AAC(3)-II and AAC(6')-Ib. Diagn Microbiol Infect Dis 78:66-69. 10.1016/j.diagmicrobio.2013.10.001

Healey KR, Zhao Y, Perez WB, Lockhart SR, Sobel JD, Farmakiotis D, Kontoyiannis DP, Sanglard D, Taj-Aldeen SJ, Alexander BD, Jimenez-Ortigosa C, Shor E, and Perlin DS. 2016. Prevalent mutator genotype identified in fungal pathogen Candida glabrata promotes multi-drug resistance. Nat Commun 7:11128. 10.1038/ncomms11128

Henegariu O, Heerema NA, Dlouhy SR, Vance GH, and Vogt PH. 1997. Multiplex PCR: critical parameters and step-by-step protocol. Biotechniques 23:504-511. 10.2144/97233rr01

Hong Y, Liu T, Lee MD, Hofacre CL, Maier M, White DG, Ayers S, Wang L, Berghaus R, and Maurer J. 2009. A rapid screen of broth enrichments for Salmonella enterica serovars enteritidis, Hadar, Heidelberg, and Typhimurium by Using an allelotyping multiplex PCR that targets O- and H-antigen alleles. J Food Prot 72:2198-2201.

Peer) reviewing PDF | (2019:06:38709:2:0:NEW 29 Feb 2020) 
316 Jami Al-Ahmadi G, and Zahmatkesh Roodsari R. 2016. Fast and specific detection of

317 Pseudomonas Aeruginosa from other pseudomonas species by PCR. Ann Burns Fire $318 \quad$ Disasters 29:264-267.

319 Jana S, and Deb JK. 2006. Molecular understanding of aminoglycoside action and resistance.

320

321

322

323

324

325

326

327

328

329

330

331

332

333

334

335

336 Appl Microbiol Biotechnol 70:140-150. 10.1007/s00253-005-0279-0

Khosravi AD, Jenabi A, and Montazeri EA. 2017. Distribution of genes encoding resistance to aminoglycoside modifying enzymes in methicillin-resistant Staphylococcus aureus (MRSA) strains. Kaohsiung J Med Sci 33:587-593. 10.1016/j.kjms.2017.08.001

Kim TH, Hwang HJ, and Kim JH. 2017. Development of a Novel, Rapid Multiplex Polymerase Chain Reaction Assay for the Detection and Differentiation of Salmonella enterica Serovars Enteritidis and Typhimurium Using Ultra-Fast Convection Polymerase Chain Reaction. Foodborne Pathog Dis 14:580-586. 10.1089/fpd.2017.2290

Krause KM, Serio AW, Kane TR, and Connolly LE. 2016. Aminoglycosides: An Overview. Cold Spring Harb Perspect Med 6. 10.1101/cshperspect.a027029

Laamiri N, Fallgren P, Zohari S, Ben Ali J, Ghram A, Leijon M, and Hmila I. 2016. Accurate Detection of Avian Respiratory Viruses by Use of Multiplex PCR-Based Luminex Suspension Microarray Assay. J Clin Microbiol 54:2716-2725. 10.1128/JCM.00610-16

Lee N, Kwon KY, Oh SK, Chang HJ, Chun HS, and Choi SW. 2014. A multiplex PCR assay for simultaneous detection of Escherichia coli O157:H7, Bacillus cereus, Vibrio parahaemolyticus, Salmonella spp., Listeria monocytogenes, and Staphylococcus aureus in Korean ready-to-eat food. Foodborne Pathog Dis 11:574-580. 10.1089/fpd.2013.1638 
337 Levin-Reisman I, Ronin I, Gefen O, Braniss I, Shoresh N, and Balaban NQ. 2017. Antibiotic

338 tolerance facilitates the evolution of resistance. Science 355:826-830.

$339 \quad 10.1126 /$ science.aaj2191

340 Li C, Shi Y, Yang G, Xia X-s, Mao X, Fang Y, Zhang A-M, and Song Y. 2019. Establishment of

341 loop-mediated isothermal amplification for rapid detection of Pseudomonas aeruginosa. EXPERIMENTAL AND THERAPEUTIC MEDICINE:6. 10.3892/etm.2018.6910

343

344

345

346

347

348

349

350

351

352

353

354

355

356

357

Magiorakos AP, Srinivasan A, Carey RB, Carmeli Y, Falagas ME, Giske CG, Harbarth S, Hindler JF, Kahlmeter G, Olsson-Liljequist B, Paterson DL, Rice LB, Stelling J, Struelens MJ, Vatopoulos A, Weber JT, and Monnet DL. 2012. Multidrug-resistant, extensively drug-resistant and pandrug-resistant bacteria: an international expert proposal for interim standard definitions for acquired resistance. Clin Microbiol Infect 18:268-281. 10.1111/j.1469-0691.2011.03570.x

Magnet S, and Blanchard JS. 2005. Molecular insights into aminoglycoside action and resistance. Chem Rev 105:477-498. 10.1021/cr0301088

Moran RA, Anantham S, Holt KE, and Hall RM. 2017. Prediction of antibiotic resistance from antibiotic resistance genes detected in antibiotic-resistant commensal Escherichia coli using PCR or WGS. J Antimicrob Chemother 72:700-704. 10.1093/jac/dkw511

Mu XQ, Liu BB, Hui E, Huang W, Yao LC, Duo LB, Sun WY, Li GQ, Wang FX, and Liu SL. 2016. A rapid loop-mediated isothermal amplification (LAMP) method for detection of the macrolide-streptogramin type B resistance gene msrA in Staphylococcus aureus. $J$ Glob Antimicrob Resist 7:53-58. 10.1016/j.jgar.2016.07.006 
358 Nagar A, and Hahsler M. 2013. Fast discovery and visualization of conserved regions in DNA 359 sequences using quasi-alignment. BMC Bioinformatics 14 Suppl 11:S2. 10.1186/1471360 2105-14-S11-S2

361

362

363

364

365

366

367

368

369

370

371

372

373

374

375

376

377

378

Nasiri G, Peymani A, Farivar TN, and Hosseini P. 2018. Molecular epidemiology of aminoglycoside resistance in clinical isolates of Klebsiella pneumoniae collected from Qazvin and Tehran provinces, Iran. Infect Genet Evol 64:219-224. 10.1016/j.meegid.2018.06.030

Odumosu BT, Adeniyi BA, and Chandra R. 2015. Occurrence of aminoglycoside-modifying enzymes genes (aac(6')-I and ant(2")-I) in clinical isolates of Pseudomonas aeruginosa from Southwest Nigeria. Afr Health Sci 15:1277-1281. 10.4314/ahs.v15i4.29

Ojdana D, Sienko A, Sacha P, Majewski P, Wieczorek P, Wieczorek A, and Tryniszewska E. 2018. Genetic basis of enzymatic resistance of E. coli to aminoglycosides. Adv Med Sci 63:9-13. 10.1016/j.advms.2017.05.004

Panek J, Frac M, and Bilinska-Wielgus N. 2016. Comparison of Chemical Sensitivity of Fresh and Long-Stored Heat Resistant Neosartorya fischeri Environmental Isolates Using BIOLOG Phenotype MicroArray System. PLoS One 11:e147605. 10.1371/journal.pone.0147605

Park SH, and Ricke SC. 2015. Development of multiplex PCR assay for simultaneous detection of Salmonella genus, Salmonella subspecies I, Salm. Enteritidis, Salm. Heidelberg and Salm. Typhimurium. J Appl Microbiol 118:152-160. 10.1111/jam.12678

Pham NT, Ushijima H, Thongprachum A, Trinh QD, Khamrin P, Arakawa C, Ishii W, Okitsu S, 
379

380

381

382

383

384

385

386

387

388

389

390

391

392

393

394

395

396

397

398

399

Komine-Aizawa S, and Hayakawa S. 2017. Multiplex PCR for the Detection of 10

Viruses Causing Encephalitis/Encephalopathy and its Application to Clinical Samples

Collected from Japanese Children with Suspected Viral. Clin Lab 63:91-100. 10.7754/Clin.Lab.2016.160630

Phaneuf CR, Oh K, Pak N, Saunders DC, Conrardy C, Landers JP, Tong S, and Forest CR. 2013. Sensitive, microliter PCR with consensus degenerate primers for Epstein Barr virus amplification. Biomed Microdevices 15:221-231. 10.1007/s10544-012-9720-1

Planet PJ. 2017. Life After USA300: The Rise and Fall of a Superbug. J Infect Dis 215:S71-S77. 10.1093/infdis/jiw444

Quainoo S, Coolen JPM, van Hijum S, Huynen MA, Melchers WJG, van Schaik W, and Wertheim HFL. 2017. Whole-Genome Sequencing of Bacterial Pathogens: the Future of Nosocomial Outbreak Analysis. Clin Microbiol Rev 30:1015-1063. 10.1128/CMR.0001617

Ramirez MS, and Tolmasky ME. 2010. Aminoglycoside modifying enzymes. Drug Resist Updat 13:151-171. 10.1016/j.drup.2010.08.003

Skodvin B, Aase K, Brekken AL, Charani E, Lindemann PC, and Smith I. 2017. Addressing the key communication barriers between microbiology laboratories and clinical units: a qualitative study. J Antimicrob Chemother 72:2666-2672. 10.1093/jac/dkx163

Su M, Satola SW, and Read TD. 2019. Genome-Based Prediction of Bacterial Antibiotic Resistance. J Clin Microbiol 57. 10.1128/JCM.01405-18

Tamburro M, and Ripabelli G. 2017. High Resolution Melting as a rapid, reliable, accurate and 
400

401

402

403

404

405

406

407

408

409

410

411

412

413

414

415

416

417

418

419

420

cost-effective emerging tool for genotyping pathogenic bacteria and enhancing molecular

epidemiological surveillance: a comprehensive review of the literature. Ann Ig 29:293-

316. 10.7416/ai.2017.2153

Tseng SH, Lee CM, Lin TY, Chang SC, Chuang YC, Yen MY, Hwang KP, Leu HS, Yen CC, and Chang FY. 2012. Combating antimicrobial resistance: antimicrobial stewardship program in Taiwan. J Microbiol Immunol Infect 45:79-89. 10.1016/j.jmii.2012.03.007

Tuttle MS, Mostow E, Mukherjee P, Hu FZ, Melton-Kreft R, Ehrlich GD, Dowd SE, and Ghannoum MA. 2011. Characterization of bacterial communities in venous insufficiency wounds by use of conventional culture and molecular diagnostic methods. $J$ Clin Microbiol 49:3812-3819. 10.1128/JCM.00847-11

Vaziri F, Peerayeh SN, Nejad QB, and Farhadian A. 2011. The prevalence of aminoglycosidemodifying enzyme genes (aac (6')-I, aac (6')-II, ant (2")-I, aph (3')-VI) in Pseudomonas aeruginosa. Clinics (Sao Paulo) 66:1519-1522.

Wagner EK, and Maynard JA. 2018. Engineering therapeutic antibodies to combat infectious diseases. Curr Opin Chem Eng 19:131-141. 10.1016/j.coche.2018.01.007

Xiao Y, and Hu Y. 2012. The major aminoglycoside-modifying enzyme AAC(3)-II found in Escherichia coli determines a significant disparity in its resistance to gentamicin and amikacin in China. Microb Drug Resist 18:42-46. 10.1089/mdr.2010.0190

Yadegar A, Sattari M, Mozafari NA, and Goudarzi GR. 2009. Prevalence of the genes encoding aminoglycoside-modifying enzymes and methicillin resistance among clinical isolates of Staphylococcus aureus in Tehran, Iran. Microb Drug Resist 15:109-113. 
422 Zarate SG, De la Cruz Claure ML, Benito-Arenas R, Revuelta J, Santana AG, and Bastida A.

423 2018. Overcoming Aminoglycoside Enzymatic Resistance: Design of Novel Antibiotics and Inhibitors. Molecules 23. 10.3390/molecules23020284

425 Zavascki AP, Klee BO, and Bulitta JB. 2017. Aminoglycosides against carbapenem-resistant 426 Enterobacteriaceae in the critically ill: the pitfalls of aminoglycoside susceptibility. Expert Rev Anti Infect Ther 15:519-526. 10.1080/14787210.2017.1316193 
428

429

430

431

432

433

434

435

436

437

438

439

440

441

442

443

444

445

446

447

448

\section{Figure legend}

Figure 1 The sensitivity and accuracy evaluation of $\operatorname{Aac}\left(6^{\prime}\right)-\operatorname{Ib}, \operatorname{Ant}\left(3^{\prime \prime}\right)-\operatorname{Ia}, \operatorname{Aph}\left(3^{\prime}\right)-\operatorname{Ia}$, and

Aac(3)-II resistance genes by S-PCR. The serially diluted positive plasmids with resistance

gene were used as the template in the sensitivity evaluation of S-PCR, at the concentrations from

$3 \times 10^{9}-3 \times 10^{0}, 4 \times 10^{9}-4 \times 10^{0}, 5 \times 10^{9}-5 \times 10^{0}$, and $4 \times 10^{10}-4 \times 10^{10}$ copies $/ \mu \mathrm{L}$ respectively, with

nuclease-free water used as template for NC. Meanwhile, the four resistance genes were detected in the 237 clinical strains of E. coli, the bacterial solution as the S-PCR template. All

experiments were repeated six times. $\mathrm{NC}$, negative control; $\mathrm{M}$, marker.

Figure 2 Establishment of M-PCR reaction system. From lane 1 to 4, the positive plasmids with $A a c\left(6^{\prime}\right)-I b, A n t\left(3^{\prime \prime}\right)-I a, A p h\left(3^{\prime}\right)-I a$, and $A a c(3)-I I$ respectively were used as the template for M-PCR amplification. E. coli $1611 \mathrm{NY} 0004$ with the four drug resistance genes was used as the template for M-PCR reaction in lane 5, with nuclease-free water used as template for NC. NC, negative control; $\mathrm{M}$, marker.

Figure 3 The accuracy evaluation of M-PCR. From lane 2 to 6 , the template for the accuracy evaluation of M-PCR were the bacterial solution of the 5 clinical strains (1611NY0004, 1611UR0282, 1611SP0549, 1611UR0062, 1611UR0215) with four resistance genes. The four equal concentration plasmids with $A a c\left(6^{\prime}\right)-I b, A n t\left(3^{\prime \prime}\right)-I a, A p h\left(3^{\prime}\right)-I a$, and $A a c(3)-I I$ resistance genes were mixed together as the positive control in lane 1, with nuclease-free water used as template for NC. PC, positive control; NC, negative control; M, marker.

Figure 4 The sensitivity evaluation of M-PCR. (A) The four equal concentration plasmids with $A a c\left(6^{\prime}\right)-I b, A n t\left(3^{\prime \prime}\right)-I a, A p h\left(3^{\prime}\right)-I a$, and $A a c(3)-I I$ resistance genes were mixed, and serially 
449 diluted as 10 -fold $\left(1 \times 10^{8}-1 \times 10^{0}\right)$, as the sensitivity evaluation of M-PCR. The nuclease-free

450 water used in lane 10 as template for NC. (B) The E. coli 1611 NY0004 strain with four resistance

451 genes was used as the template for the the sensitivity evaluation of M-PCR. The bacterial

452 solution was serially diluted as 10 -fold $\left(1 \times 10^{8}-1 \times 10^{0}\right)$. The nuclease-free water used in lane 10

453 as template for NC. NC, negative control; M, marker.

454

455

456 
Table $\mathbf{1}$ (on next page)

Tabel 1

Table 1 Primers used in this study 
Table 1 Primers used in this study

2

\begin{tabular}{|c|c|c|c|c|}
\hline Gene & Primers & Sequence $\left(5^{\prime}-3^{\prime}\right)$ & Product size (bp) & Annealing temperature $\left({ }^{\circ} \mathrm{C}\right)$ \\
\hline \multirow{3}{*}{$\operatorname{Aac}\left(6^{\prime}\right)-I$} & $\operatorname{Aac}\left(6^{\prime}\right)-I-\mathrm{F}$ & AAACCCCGCTTTCTCGTAGC & \multirow{3}{*}{112} & \multirow{3}{*}{57} \\
\hline & & & & \\
\hline & $\operatorname{Aac}\left(6^{\prime}\right)-I-\mathrm{R}$ & AAACCCCGCTTTCTCGTAGC & & \\
\hline \multirow{3}{*}{$\operatorname{Ant}\left(3^{\prime}\right)$} & $\operatorname{Ant}\left(3^{\prime}\right)-\mathrm{F}$ & CCGGTTCCTGAACAGGATC & \multirow{3}{*}{180} & \multirow{3}{*}{59} \\
\hline & & & & \\
\hline & $\operatorname{Ant}\left(3^{\prime}\right)-\mathrm{R}$ & CCCAGTCGGCAGCGACATC & & \\
\hline \multirow[t]{3}{*}{$\operatorname{Aph}\left(3^{\prime}\right)$} & $\operatorname{Aph}\left(3^{\prime}\right)-\mathrm{F}$ & CAAGATGGATTGCACGCAGG & \multirow{3}{*}{317} & \multirow{3}{*}{56} \\
\hline & & & & \\
\hline & $\operatorname{Aph}\left(3^{\prime}\right)-\mathrm{R}$ & TTCAGTGACAACGTCGAGCA & & \\
\hline \multirow[t]{3}{*}{$\operatorname{Aac}(3)-I I$} & $\operatorname{Aac}(3)-I I-\mathrm{F}$ & GCTCGGTTGGATGACAAAGC & \multirow{3}{*}{379} & \multirow{3}{*}{57} \\
\hline & & & & \\
\hline & $\operatorname{Aac}(3)-I I-\mathrm{R}$ & AGGCGACTTCACCGTTTCTT & & \\
\hline
\end{tabular}




\section{Figure 1}

Figure 1 The sensitivity and accuracy evaluation of $A a c\left(6^{\prime}\right)-l b, A n t\left(3^{\prime \prime}\right)-l a, A p h\left(3^{\prime}\right)-l a$, and $A a c(3)$-II resistance genes by S-PCR.

The serially diluted positive plasmids with resistance gene were used as the template in the sensitivity evaluation of S-PCR, at the concentrations from $3 \times 10^{9}-3 \times 10^{0}, 4 \times 10^{9}-4 \times 10^{0}$, $5 \times 10^{9}-5 \times 10^{0}$, and $4 \times 10^{10}-4 \times 10^{10}$ copies/ $\mu \mathrm{L}$ respectively, with nuclease $\square$ free water used as template for NC. Meanwhile, the four resistance genes were detected in the 237 clinical strains of E. coli, the bacterial solution as the S-PCR template. All experiments were repeated six times. NC, negative control; $M$, marker.
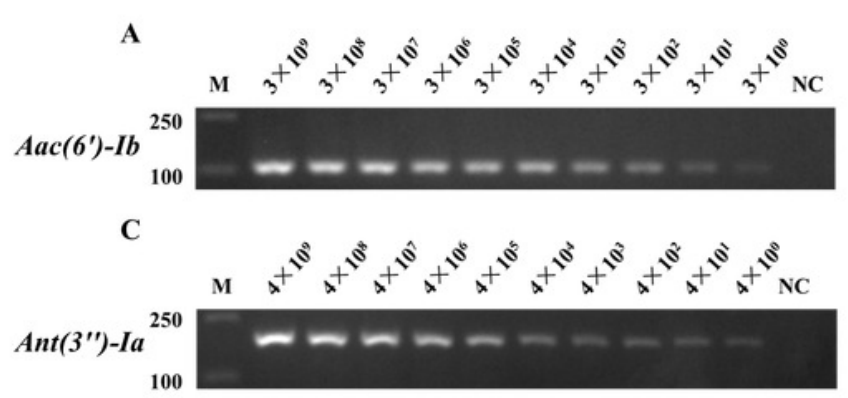

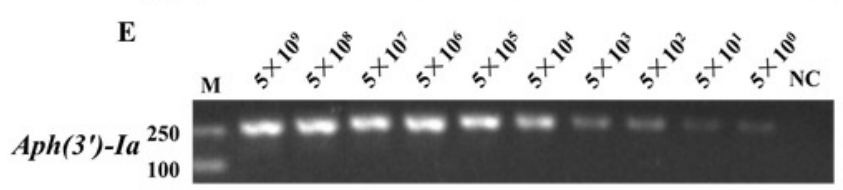

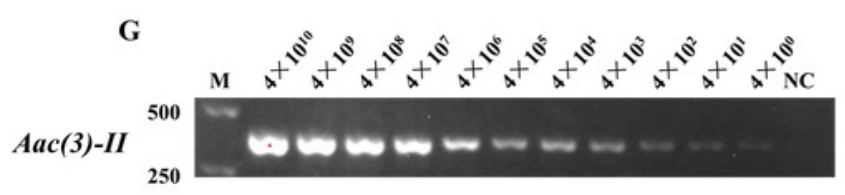

B







\section{Figure 2}

Figure 2 Establishment of M-PCR reaction system.

From lane 1 to 4, the positive plasmids with $A a c\left(6^{\prime}\right)-I b$, Ant( $\left.3^{\prime \prime}\right)-I a, A p h\left(3^{\prime}\right)-I a$, and $A a c(3)-I I$ respectively were used as the template for M-PCR amplification. E. coli 1611 NY0004 with the four drug resistance genes was used as the template for M-PCR reaction in lane 5, with nuclease $\square$ free water used as template for NC. NC, negative control; M, marker.






\section{Figure 3}

Figure 3 The accuracy evaluation of M-PCR.

From lane 2 to 6 , the template for the accuracy evaluation of M-PCR were the bacterial solution of the 5 clinical strains (1611NY0004, 1611UR0282, 1611SP0549, 1611UR0062, 1611UR0215) with four resistance genes. The four equal concentration plasmids with $\operatorname{Aac}\left(6^{\prime}\right)$ Ib, Ant( (3")-Ia, Aph( (3')-Ia, and Aac(3)-II resistance genes were mixed together as the positive control in lane 1, with nuclease $\square$ free water used as template for NC. PC, positive control; NC, negative control; $\mathrm{M}$, marker.
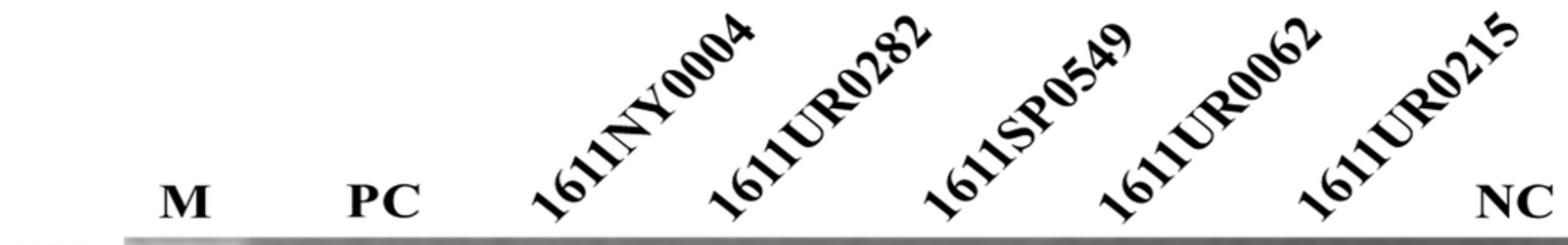

500

250

100 


\section{Figure 4}

Figure 4 The sensitivity evaluation of M-PCR.

(a) The four equal concentration plasmids with $A a c\left(6^{\prime}\right)-I b, A n t\left(3^{\prime \prime}\right)-l a, A p h\left(3^{\prime}\right)-l a$, and $A a c(3)-I I$ resistance genes were mixed, and serially diluted as 10 -fold $\left(1 \times 10^{8}-1 \times 10^{0}\right)$, as the sensitivity evaluation of M-PCR. The nuclease $\square$ free water used in lane 10 as template for NC. (b) The $E$. coli 1611NY0004 strain with four resistance genes was used as the template for the the sensitivity evaluation of M-PCR. The bacterial solution was serially diluted as 10 -fold $\left(1 \times 10^{8}-1 \times 10^{0}\right)$. The nuclease $[$ free water used in lane 10 as template for NC. NC, negative control; M, marker.
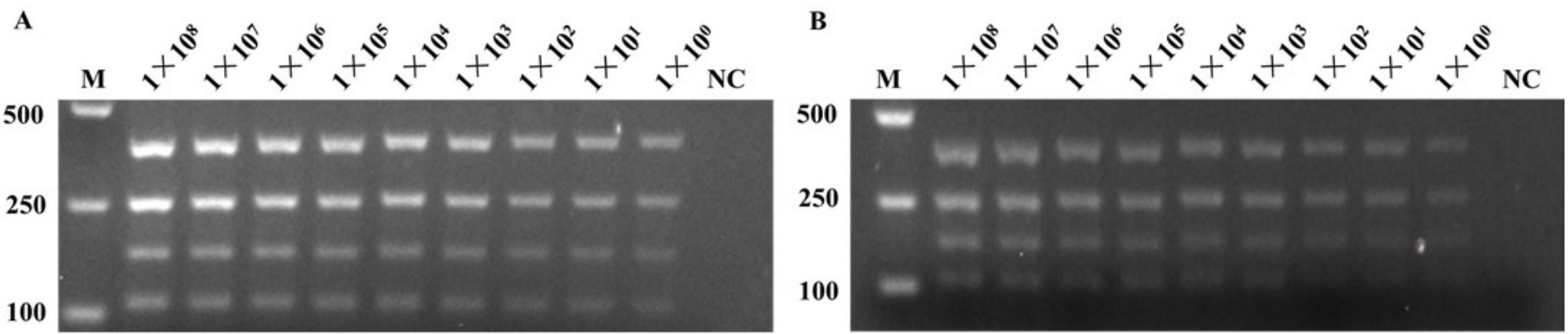